\title{
A New Synthesis of Lysergic Acid
}

\author{
Jamea B. Hendrickson and Jian Wang \\ Department of Chemistry \\ Brandeis University \\ Waltham MA 02454-9110
}

1H and 13C NMR spectra were recorded on a Varian Unity Inova $400 \mathrm{MHz}$ instrument at ambient temperature using TMS as internal standard and $\mathrm{CDCl}_{3}$ as solvent. Mass spectrometry was recorded on the Micromass QUATTRO II instrument. The solvents and reagents were purified by the following methods: diethyl ether, glyme and THF were distilled from sodium with benzophenone as an indicator. DMF, $\mathrm{CH}_{2} \mathrm{Cl}_{2}$ and xylene were distilled from calcium hydride. Benzene and toluene were distilled from $\mathrm{P}_{2} \mathrm{O}_{5}$. Methanol and ethanol were dried over magnesium ${ }^{85}$. Triglyme was distilled from $\mathrm{LiAlH}_{4}$. Trimethylamine was distilled from $\mathrm{NaOH}$. Anhydrous $\mathrm{CaCl}_{2}$ has been roasted in a crucible and allowed to cool in a desiccator.

\section{4-Bromo-indole (2a):}

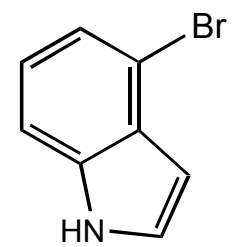

To a solution of 3-methoxycarbonylindole $(7.0 \mathrm{~g}, 40.0 \mathrm{mmol})$ in TFA was added Thallium (III) trifluoroacetate $(32.6 \mathrm{~g}, 60.0 \mathrm{mmol})$ in TFA $(140 \mathrm{ml})$, and the mixture was stirred for 2 hours at r.t. After TFA was evaporated in vacuo, a dark brown oil was obtained. This oil was dissolved in DMF $(100 \mathrm{ml})$ and $\mathrm{CuBr}_{2}(35.8 \mathrm{~g}, 160.0 \mathrm{mmol})$ was added. The reaction was stirred at $120^{\circ} \mathrm{C}$ for 1 hour then was cooled and $\mathrm{CH}_{2} \mathrm{Cl}_{2}: \mathrm{MeOH}(95: 5$, v/v) $(300 \mathrm{ml})$ was added. Insoluble precipitates were filtered off through a plug of celite. The filtrate was washed with brine $\left(100 \mathrm{ml}\right.$ x 2), and the organic layer was dried over $\mathrm{NaSO}_{4}$. A crystalline material $(7.60 \mathrm{~g})$ was obtained in $63 \%$ yield after the removal of solvent under reduced pressure. This material was directly subjected to decarboxylation for the preparation of 4-bromo-indole in the next step.

To a solution of 4-bromo-indole-3-carboxylic acid methyl ester $(5.06 \mathrm{~g}, 20.0 \mathrm{mmol})$ in 200 $\mathrm{ml}$ methanol was added $200 \mathrm{ml}$ of $40 \%$ aq. $\mathrm{NaOH}$. The reaction was refluxed for $1.5 \mathrm{~h}$ with stirring. After evaporation of the solvent, the residue was poured into $200 \mathrm{ml}$ water, and extracted with $\mathrm{CH}_{2} \mathrm{Cl}_{2}: \mathrm{MeOH}(95: 5, \mathrm{v} / \mathrm{v} ; 200 \mathrm{ml} \mathrm{x} \mathrm{3)}$ ). The extract was washed with brine, dried over $\mathrm{Na}_{2} \mathrm{SO}_{4}$, and evaporated in vacuo to leave a brown oil. Purification by chromatography using hexane : ethyl acetate (6:1) afforded a light colored oil $(2.68 \mathrm{~g})$ in $69.1 \%$ yield. 
${ }^{1} \mathrm{H} \mathrm{NMR}\left(\mathrm{CDCl}_{3}\right): \delta 6.62(\mathrm{t}$-like m, $\left.1 \mathrm{H}), 7.05(\mathrm{dd}, 1 \mathrm{H}, \mathrm{J}=8.2,8.2 \mathrm{~Hz})\right), 7.24(\mathrm{~m}, 1 \mathrm{H}),$, $(\mathrm{d}, 1 \mathrm{H}, \mathrm{J}=8.2 \mathrm{~Hz}), 7.34(\mathrm{~d}, 1 \mathrm{H}, \mathrm{J}=8.2 \mathrm{~Hz}), 8.28(\mathrm{bs}, 1 \mathrm{H}) .{ }^{13} \mathrm{C} \mathrm{NMR}\left(\mathrm{CDCl}_{3}\right): \delta 136.7$, 128.2, 125.5, 123.1, 122.9, 115.2, 111.0, 103.5. Mass Spectrum $(\mathrm{M}+1)$ : Expected for $\mathrm{C}_{8} \mathrm{H}_{6} \mathrm{BrN}$ : 195.97. Found: 195.97. Elemental Analysis: Calcd. For $\mathrm{C}_{8} \mathrm{H}_{6} \mathrm{BrN}: \mathrm{C}, 49.01 ; \mathrm{H}$, 3.08 ; N, 7.14. Found: C, 48.83; H, 3.07; N, 7.28.

\section{4-Iodo-indole (2b):}

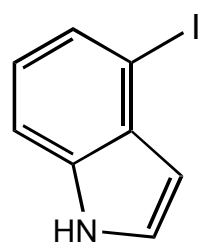

To a solution of 3-methoxycarbonylindole $(7.0 \mathrm{~g}, 40.0 \mathrm{mmol})$ in TFA was added Thallium (III) trifluoroacetate $(32.6 \mathrm{~g}, 60.0 \mathrm{mmol})$ in TFA $(140 \mathrm{ml})$, and the mixture was stirred for 2 hours at r.t. After TFA was evaporated in vacuo, a dark brown oil was obtained. This oil was suspended in $450 \mathrm{ml} \mathrm{H}_{2} \mathrm{O}$, and $\mathrm{KI}(19.9 \mathrm{~g}, 120.0 \mathrm{mmol})$ was added to this suspension. The reaction was stirred at r. t. for 2 hours. $\mathrm{CH}_{2} \mathrm{Cl}_{2}: \mathrm{MeOH}(95: 5, \mathrm{v} / \mathrm{v})(300$ $\mathrm{ml}$ ) was added to the reaction mixture and insoluble precipitates were filtered off through a plug of celite. The organic layer was separated and washed with aq. sodium thiosulfate then brine. Removal of the solvent left a brownish solid. Quick purification by a short plug of silica gel afforded a white solid (8.68g) as 4-iodo-indole-3-carboxylic acid methyl ester in $72.1 \%$ yield. This material was used directly in the next step.

To a solution of 4-iodo-indole-3-carboxylic acid methyl ester (6.02g, $20.0 \mathrm{mmol})$ in 200 $\mathrm{ml}$ methanol was added $200 \mathrm{ml}$ of $40 \%$ aq. $\mathrm{NaOH}$. The reaction was refluxed for $1.5 \mathrm{~h}$ with stirring. After evaporation of the solvent, the residue was poured into $200 \mathrm{ml}$ water, and extracted with $\mathrm{CH}_{2} \mathrm{Cl}_{2}: \mathrm{MeOH}(95: 5, \mathrm{v} / \mathrm{v} ; 200 \mathrm{ml}$ x 3). The extract was washed with brine, dried over $\mathrm{Na}_{2} \mathrm{SO}_{4}$, and evaporated in vacuo to leave an off-white solid. Purification by chromatography using hexane : ethyl acetate $(6: 1)$ afforded a white crystalline solid $(3.51 \mathrm{~g})$ in $72.3 \%$ yield.

${ }^{1} \mathrm{H} \mathrm{NMR}\left(\mathrm{CDCl}_{3}\right): \delta 8.30$ (bs $\left.1 \mathrm{H}\right), 7.52(\mathrm{~d}, 1 \mathrm{H}, \mathrm{J}=8.4 \mathrm{~Hz}), 7.34(\mathrm{~d}, 1 \mathrm{H}, \mathrm{J}=8.4 \mathrm{~Hz}), 7.20(\mathrm{~m}$, $1 \mathrm{H}), 6.92(\mathrm{t}, 1 \mathrm{H}, \mathrm{J}=8.4 \mathrm{~Hz}), 6.48(\mathrm{t}-\mathrm{like} \mathrm{m}, 1 \mathrm{H}) .{ }^{13} \mathrm{C} \mathrm{NMR}\left(\mathrm{CDCl}_{3}\right): \delta 135.4,133.2,130.1$, 125.2, 124.1, 111.8, 107.1, 88.2. Mass Spectrum $(\mathrm{M}+1)$ : Expected for $\mathrm{C}_{8} \mathrm{H}_{6} \mathrm{IN}$ : 243.95 . Found: 243.95. Elemental Analysis: Calcd. For $\mathrm{C}_{8} \mathrm{H}_{6} \mathrm{IN}$ : C, 39.53; H, 2.49; N, 5.76. Found: C, 39.67; H, 2.59; N, 5.75 .

\section{Pyridine-2,5-dicarboxylic acid 5-methyl ester (3):}<smiles>CC(=O)c1ccc(C(=O)O)nc1</smiles> 
To a solution of pyridine-2,5-dicarboxylic acid dimethyl ester $(5.91 \mathrm{~g}, 30 \mathrm{mmol})$ in 100 $\mathrm{ml}$ methanol was added copper(II) nitrate trihydrate $(14.5 \mathrm{~g}, 60 \mathrm{mmol})$ in a $500 \mathrm{ml}$ round bottom flask equipped with a reflux condenser and a stirring bar. The reaction was refluxed for 80 mins. A deep violet-blue precipitation was observed after 20 mins and lasted throughout the course of the reaction. The reaction was cooled to r.t., and the reaction mixture was reduced to $1 / 3$ of its original volume. The deep violet-blue solid was collected by filtration and washed with cold methanol then cold water. This solid material was dissolved in $50 \mathrm{ml}$ glyme, and $\mathrm{H}_{2} \mathrm{~S}$ gas was bubbled into the solution. The black precipitate was formed in 2 mins, and the deep violet-blue solid disappeared after 15 mins. The black precipitate was filtered out through a plug of celite and the filtrate was concentrated to $20 \mathrm{ml}$. Excess hexanes were added into this solution, and a white solid was formed. The white solid was collected by filtration. Recrystallization of this solid from acetone afforded $4.83 \mathrm{~g}$ product in $88.9 \%$ yield ( mp. $\left.194.1-195.1{ }^{\circ} \mathrm{C}, \mathrm{Lit}^{6}\right) .{ }^{1} \mathrm{H}$ $\operatorname{NMR}\left(\mathrm{CDCl}_{3}\right): \delta 9.21(\mathrm{~s}, 1 \mathrm{H}), 8.60(\mathrm{~d}, 1 \mathrm{H}, \mathrm{J}=2.9 \mathrm{~Hz}), 8.23(\mathrm{~d}, 1 \mathrm{H}, \mathrm{J}=2.9 \mathrm{~Hz}), 4.00(\mathrm{~s}, 3 \mathrm{H})$. ${ }^{13} \mathrm{C}$ NMR $\left(\mathrm{CDCl}_{3}\right): \delta 172.4,165.3,154.3,150.4,139.2,129.3,122.9$, 52.3. Mass Spectrum $(\mathrm{M}+1)$ : Expected for $\mathrm{C}_{8} \mathrm{H}_{7} \mathrm{NO}_{4}$ : 182.04. Found: 182.04. Elemental Analysis: Calcd. For $\mathrm{C}_{8} \mathrm{H}_{7} \mathrm{NO}_{4}$ : C, 53.04; H, 3.89; N, 7.73. Found: C, 52.91; H, 3.88; N, 7.86.

\section{6-(4-Iodo-indole-3-carbonyl)-nicotinic acid methyl ester (4b):

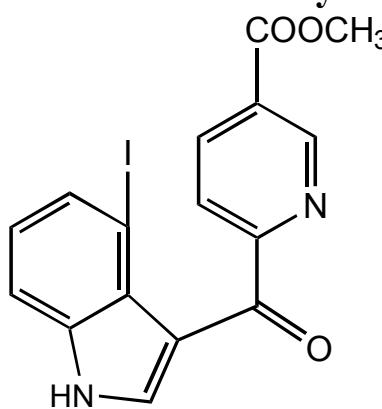

To a solution of EtMgBr $(10 \mathrm{ml}, 1.575 \mathrm{M}$ in ether, $15.75 \mathrm{mmol})$ was added a solution of 4-iodo-1H-indole $(3.65 \mathrm{~g}, 15.0 \mathrm{mmol}$ ) in ether (anhydrous, $20 \mathrm{ml}$ ). The resulting twophase system was allowed to stand for 15 min under stirring whereupon $\mathrm{ZnCl}_{2}(15 \mathrm{ml}$, $1.0 \mathrm{~m}$ in ether, $15.0 \mathrm{mmol}$ ) was added with stirring. The two-phase system was allowed to stand for 30 min when 6-chlorocarbonyl-nicotinic acid methyl ester $(3.14 \mathrm{~g}, 15.75 \mathrm{mmol})$ in anhydrous ether $(10 \mathrm{ml})$ was added rapidly under vigorous stirring. The reaction mixture was allowed to stand for 2 hours whereupon $\mathrm{NH}_{4} \mathrm{Cl}$ (aq. sat. $25 \mathrm{ml}$ ) was added. The organic layer was separated, and the aqueous layer was extracted with $\mathrm{CH}_{2} \mathrm{Cl}_{2}$ ( 50 $\mathrm{ml} \times 3$ ). The combined organic layer was washed with $\mathrm{NaHCO}_{3}$ (aq. sat. $25 \mathrm{ml}$ ) followed by brine $(25 \mathrm{ml})$, and dried over $\mathrm{Na}_{2} \mathrm{SO}_{4}$. Removal of the solvent in vacuo afforded a yellowish solid. Recrystallization of this solid from acetone afforded $4.25 \mathrm{~g}$ of the desired crystalline product (mp. $245.7-246.8^{\circ} \mathrm{C}$ ) in $69.8 \%$ yield.

${ }^{1} \mathrm{H}$ NMR $\left(\mathrm{CDCl}_{3}\right): \delta 9.17(\mathrm{~d}, 1 \mathrm{H}, \mathrm{J}=1.2 \mathrm{~Hz}), 8.52(\mathrm{dd}, 1 \mathrm{H}, \mathrm{J}=8.0,1.2 \mathrm{~Hz}), 8.28(\mathrm{~d}, 1 \mathrm{H}$, $\mathrm{J}=2.4 \mathrm{~Hz}), 8.22(\mathrm{~d}, 1 \mathrm{H}, \mathrm{J}=8.0 \mathrm{~Hz}), 7.75(\mathrm{~d}, 1 \mathrm{H}, \mathrm{J}=8.0 \mathrm{~Hz}), 7.63(\mathrm{~d}, 1 \mathrm{H}, \mathrm{J}=8.0 \mathrm{~Hz}), 7.00(\mathrm{t}$, $1 \mathrm{H}, \mathrm{J}=8.0 \mathrm{~Hz}$ ). ${ }^{13} \mathrm{C}$ NMR (Acetone-d6): $\delta$ 186.1, 164.5, 160.8, 148.8, 142.7, 140.8, 138.2, 137.2, 134.4, 127.7, 123.4, 122.8, 114.9, 111.4, 87.2, 52.2. Mass Spectrum (M+1): 
Expected for $\mathrm{C}_{16} \mathrm{H}_{11} \mathrm{IN}_{2} \mathrm{O}_{3}$ : 406.98. Found: 406.98. Elemental Analysis: Calcd. For $\mathrm{C}_{16} \mathrm{H}_{11} \mathrm{IN}_{2} \mathrm{O}_{3}$ : C, 47.31; H, 2.73; N, 6.90. Found: C, 47.50; H, 2.60; N, 6.88.

\section{3-Chloro-pyridine-2,5-dicarboxylic acid dimethyl ester (7):}<smiles>COC(=O)c1ncc(C(C)=O)cc1Cl</smiles>

Pyridine-2,5-dicarboxylic acid $(8.35 \mathrm{~g}, 50.0 \mathrm{mmol})$ was suspended in $250 \mathrm{ml} 0.2 \%(\mathrm{w} / \mathrm{w})$ aq. $\mathrm{Na}_{2} \mathrm{WO}_{4}(0.5 \mathrm{~g})$ in a 1 liter round bottom flask. To this solution was added $\mathrm{H}_{2} \mathrm{O}_{2}$ in water $(30 \% \mathrm{w} / \mathrm{w}, 8.5 \mathrm{~g}, 75.0 \mathrm{mmol})$. The resulting mixture was stirred and heated at $80-$ $85^{\circ} \mathrm{C}$ for 10 hours. The resulting solid was collected by filtration and washed with cold water. Drying the material under vacuum overnight yielded $9.06 \mathrm{~g}$ product solid (mp. 253.2-254. $1^{\circ} \mathrm{C}$, dec; Lit. ${ }^{9} 254^{\circ} \mathrm{C}$, dec.) as pyridine-2,5-dicarboxylic acid N-oxide in $99 \%$ yield. This solid was used in the next step.

To a solution of thionyl chloride $(9.52 \mathrm{~g}, 5.84 \mathrm{ml}, 80 \mathrm{mmol})$ in $200 \mathrm{ml} \mathrm{CH}_{2} \mathrm{Cl}_{2}$ was added DMF $(2 \mathrm{ml})$ at $0^{\circ} \mathrm{C}$. Pyridine-2,5-dicarboxylic acid N-oxide $(3.66 \mathrm{~g}, 20.0 \mathrm{mmol})$ was added into this mixture portionwise. The resulting mixture was heated at $65^{\circ} \mathrm{C}$ for 2 hours. The reaction was cooled to r.t. then placed in an ice-bath. The reaction was quenched with methanol $(30 \mathrm{ml})$ slowly at $0^{\circ} \mathrm{C}$. The solvent was removed in vacuo and the crude product was partitioned between $\mathrm{CH}_{2} \mathrm{Cl}_{2}(100 \mathrm{ml})$ and aq. $\mathrm{NaHCO}_{3}$ (sat. 50 $\mathrm{ml}$ ). The organic layer was separated and the aqueous layer was extracted with additional $\mathrm{CH}_{2} \mathrm{Cl}_{2}(100 \mathrm{ml} \times 2)$. The combined organic layer was dried over $\mathrm{Na}_{2} \mathrm{SO}_{4}$ and the solvent was removed in vacuo. Purification of the crude oil through a short plug of silica gel using hexane : ethyl acetate $(2: 1)$ afforded a white solid $\left(3.73 \mathrm{~g}, \mathrm{mp} .126 .0-127.0^{\circ} \mathrm{C}\right)$ in $81.2 \%$ yield. ${ }^{1} \mathrm{H}$ NMR $\left(\mathrm{CDCl}_{3}\right): \delta 9.12(\mathrm{~d}, 1 \mathrm{H}, \mathrm{J}=1.6 \mathrm{~Hz}), 8.41(\mathrm{~d}, 1 \mathrm{H}, \mathrm{J}=1.6 \mathrm{~Hz}), 4.04(\mathrm{~s}$, $3 \mathrm{H}), 4.00(\mathrm{~s}, 3 \mathrm{H}) .{ }^{13} \mathrm{C} \mathrm{NMR}\left(\mathrm{CDCl}_{3}\right): \delta 164.2,164.0,151.8,148.0,139.9,131.2,128.3$, 53.2, 53.0. Mass Spectrum $(\mathrm{M}+1)$ : Expected for $\mathrm{C}_{9} \mathrm{H}_{8} \mathrm{ClNO}_{4}$ : 230.01. Found: 230.01 . Elemental Analysis: Calcd. for $\mathrm{C}_{9} \mathrm{H}_{8} \mathrm{ClNO}_{4}$ : C, 47.08; H, 3.51; N, 6.10. Found: C, 47.21; $\mathrm{H}, 3.56$; N, 6.27.

\section{Indole-4-boronic acid (8):}

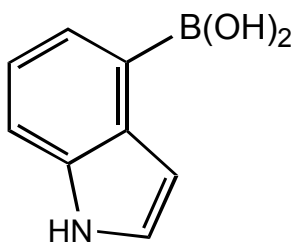


To a suspension of $\mathrm{KH}$ ( $4.57 \mathrm{~g}$ of a $30 \%$ suspension in mineral oil, $32.9 \mathrm{mmol})$ was added a solution of 4-bromo-indole $(5.88 \mathrm{~g}, 30.0 \mathrm{mmol})$ in anhydrous ether $(25 \mathrm{ml})$. The reaction was stirred at r.t. for 30 min under $\mathrm{N}_{2}$ and the reaction was cooled in an acetone-dry ice bath $\left(-78^{\circ} \mathrm{C}\right)$ with stirring. Precooled $t$-BuLi solution in hexane $(33.0 \mathrm{ml}, 66.0 \mathrm{mmol})$ was cannulated into the reaction and the reaction was kept stirring for another $20 \mathrm{~min}$. Neat $\mathrm{B}(n-\mathrm{BuO})_{3}(24.1 \mathrm{ml}, 90.0 \mathrm{mmol})$ was added into the reaction by syringe under vigorous stirring. The reaction mixture became thick when it was allowed to warm to r.t., and more anhydrous ether $(30 \mathrm{ml})$ was added under $\mathrm{N}_{2}$. The reaction was allowed to stand overnight at r.t. with vigorous stirring. The thick reaction mixture was diluted with more anhydrous ether and then transferred slowly into $1 \mathrm{M}$ aqueous $\mathrm{H}_{3} \mathrm{PO}_{4}(300 \mathrm{ml})$ at $0^{\circ} \mathrm{C}$. The mixture was stirred at r.t. for $40 \mathrm{~min}$, and extracted with ether $(100 \mathrm{ml} \mathrm{x} \mathrm{30})$. The combined organic layer was extracted with $1 \mathrm{~N} \mathrm{NaOH}(50 \mathrm{ml} \times 3)$. Ether $(100 \mathrm{ml})$ was added to this aqueous solution and the mixture was acidified to $\mathrm{pH}=2$ using $1 \mathrm{M} \mathrm{H}_{3} \mathrm{PO}_{4}$. The organic layer was separated and the aqueous layer was extracted with ether $(100 \mathrm{ml} \mathrm{x}$ 2). The combined ether layer was dried over $\mathrm{Na}_{2} \mathrm{SO}_{4}$ and evaporation of solvent in vacuo left a beige solid (4.24g, 88.0\%). ${ }^{1} \mathrm{H}$ NMR (acetone- $\mathrm{d}_{6} 80 \%+\mathrm{D}_{2} \mathrm{O} 20 \%$ ): $\delta 7.56(\mathrm{dd}, 1 \mathrm{H}$, $\mathrm{J}=7.0,1.0 \mathrm{~Hz}), 7.53(\mathrm{dd}, 1 \mathrm{H}, \mathrm{J}=8.4,1.0 \mathrm{~Hz}), 7.34(\mathrm{~d}, 1 \mathrm{H}, \mathrm{J}=3.2 \mathrm{~Hz}), 7.21(\mathrm{dd}, 1 \mathrm{H}, \mathrm{J}=8.4$, $70 \mathrm{~Hz}), 6.96(\mathrm{~d}, 1 \mathrm{H}, \mathrm{J}=3.2 \mathrm{~Hz}) .{ }^{13} \mathrm{C}$ NMR (acetone- $\mathrm{d}_{6} 80 \%+\mathrm{D}_{2} \mathrm{O} 20 \%$ ): 136.2, 132.8 , $126.6,125.5,124.9,120.2,112.8,103.4$

\section{3-(4-indolyl)-pyridine-2,5-dicarboxylic acid diethyl ester (9a):}

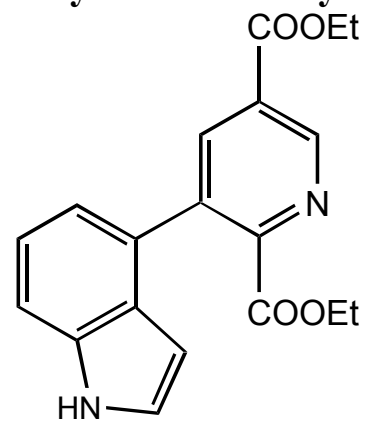

Into $500 \mathrm{ml}$ anhydrous toluene in a 1 liter round bottom flask equipped with stirring bar was bubbled in a stream of argon via a needle for $30 \mathrm{~min} . \mathrm{Pd}\left(\mathrm{PPh}_{3}\right)_{4}(0.878 \mathrm{~g}, 0.75 \mathrm{mmol})$ and 3-chloro-pyridine-2,5-dicarboxylic acid dimethyl ester $(3.44 \mathrm{~g}, 15.0 \mathrm{mmol})$ were added into this solvent and the resulting mixture was stirred at r.t. under argon for 1 hour. A solution of indole-4-boronic acid $(1.86 \mathrm{~g}, 11.5 \mathrm{mmol})$ in $50 \mathrm{ml} \mathrm{EtOH}$ and a solution of $2 \mathrm{M}$ aqueous $\mathrm{Na}_{2} \mathrm{CO}_{3}(11.5 \mathrm{ml})$ was added into the reaction mixture at r.t. under argon. The mixture was heated under argon with vigorous stirring at $105^{\circ} \mathrm{C}$ for 8 hours. The reaction mixture was cooled and brine $(200 \mathrm{ml})$ was added. The organic layer was separated and aqueous layer extracted with additional $\mathrm{CH}_{2} \mathrm{Cl}_{2}(100 \mathrm{ml} \mathrm{x}$ 2). The combined organic layer was dried over $\mathrm{Na}_{2} \mathrm{SO}_{4}$ and evaporation of the solvent left a yellowish solid. Purification of the crude material through a short plug of silica gel (hexane : ethyl acetate, 1:2) afforded a yellow solid. The TLC of this material showed it to be a mixture of three different compounds due to ester exchange. This solid was dissolved in $500 \mathrm{ml} \mathrm{EtOH}$ and the solution was stirred overnight at r.t. in the presence of cat. $\mathrm{HCl}$ in diethyl ether. A single compound (3.54g) was obtained (mp. 212.3-213.0 ${ }^{\circ} \mathrm{C}$ ) 
in $91.0 \%$ yield. ${ }^{1} \mathrm{H}$ NMR $\left(\mathrm{CDCl}_{3}\right): \delta 9.25(\mathrm{~d}, 1 \mathrm{H}, \mathrm{J}=1.6 \mathrm{~Hz}), 8.55(\mathrm{~d}, 1 \mathrm{H}, \mathrm{J}=1.6 \mathrm{~Hz}), 8.43$ (bs, $1 \mathrm{H}), 7.45(\mathrm{~d}, 1 \mathrm{H}, \mathrm{J}=8.4 \mathrm{~Hz}), 7.25-7.30(\mathrm{~m}, 2 \mathrm{H}), 7.08(\mathrm{~d}, 1 \mathrm{H}, \mathrm{J}=8.4 \mathrm{~Hz}), 6.34(\mathrm{~m}, 1 \mathrm{H})$, $4.42(\mathrm{q}, 2 \mathrm{H}, \mathrm{J}=7.2 \mathrm{~Hz}), 4.06(\mathrm{q}, 2 \mathrm{H}, \mathrm{J}=7.2 \mathrm{~Hz}), 1.41(\mathrm{t}, 3 \mathrm{H}, \mathrm{J}=7.2 \mathrm{~Hz}), 0.90(\mathrm{t}, 3 \mathrm{H}$, $\mathrm{J}=7.2 \mathrm{~Hz}) .{ }^{13} \mathrm{C} \mathrm{NMR}\left(\mathrm{CDCl}_{3}\right): \delta 166.4,164.8,142.8,149.0,140.1,136.3,135.8,129.8$, 127.6, 126.4, 125.1, 122.3, 120.2, 111.6, 100.9, 61.1, 61.2, 14.1, 13.7. Mass Spectrum $(\mathrm{M}+1)$ : Expected for $\mathrm{C}_{19} \mathrm{H}_{18} \mathrm{~N}_{2} \mathrm{O}_{4}$ : 339.13. Found: 339.13. Elemental Analysis: Calcd. for $\mathrm{C}_{19} \mathrm{H}_{18} \mathrm{~N}_{2} \mathrm{O}_{4}$ : C, 67.44; H, 5.36; N, 8.28. Found: C, 67.64; H, 5.24; N, 8.15.

\section{6-Hydroxymethyl-5-(4-indolyl)-nicotinic acid ethyl ester (9b):}

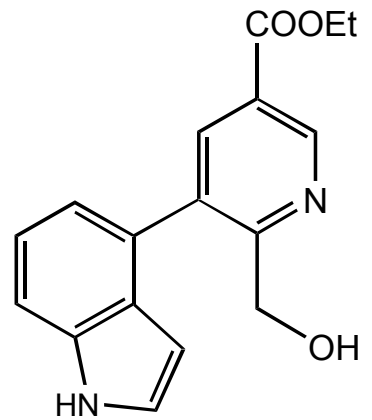

To a solution of 3-(4-indolyl)-pyridine-2,5-dicarboxylic acid diethyl ester $(0.34 \mathrm{~g}, 1.0$ $\mathrm{mmol})$ in anhydrous EtOH $(10 \mathrm{ml})$ was added $\mathrm{Ba}\left(\mathrm{BH}_{4}\right)_{2}(24.6 \mathrm{mg}, 0.65 \mathrm{mmol})$ followed by $\mathrm{CaCl}_{2}(44.3 \mathrm{mg}, 0.4 \mathrm{mmol})$ at $0^{\circ} \mathrm{C}$. The reaction was warmed to r.t. and stirred for 2 hours. $1 \mathrm{M} \mathrm{H}_{2} \mathrm{SO}_{4}(1 \mathrm{ml})$ was added to the reaction, and the resulting white precipitation $\left(\mathrm{CaSO}_{4}\right)$ was filtered out through a plug of celite. The filtrate was concentrated and partitioned between ethyl acetate $(20 \mathrm{ml})$ and $\mathrm{NaHCO}_{3}$ (aq. $\left.15 \mathrm{ml}\right)$. The organic layer was separated and the aqueous layer was extracted with additional ethyl acetate $(20 \mathrm{ml} \times 2)$. The combined organic layer was dried over $\mathrm{Na}_{2} \mathrm{SO}_{4}$, and the solvent was removed. The crude material was purified by silica gel chromatography using hexane-ethyl acetate $(3: 1$ to $1: 1)$. A colorless solid (mp. $198.1-199.0^{\circ} \mathrm{C}$ ) was obtained $(231 \mathrm{mg})$ in $78 \%$ yield.

${ }^{1} \mathrm{H} \mathrm{NMR}\left(\mathrm{CDCl}_{3}\right): \delta 9.22(\mathrm{~d}, 1 \mathrm{H}, \mathrm{J}=1.6 \mathrm{~Hz}), 8.72(\mathrm{bs}, 1 \mathrm{H}), 8.34(\mathrm{~d}, 1 \mathrm{H}, \mathrm{J}=1.6 \mathrm{~Hz}), 7.46(\mathrm{~d}$, $1 \mathrm{H}, \mathrm{J}=8.0 \mathrm{~Hz}), 7.23(\mathrm{t}, 1 \mathrm{H}, \mathrm{J}=8.0 \mathrm{~Hz}), 7.22(\mathrm{~m}, 1 \mathrm{H}), 6.98(\mathrm{~d}, 1 \mathrm{H}, \mathrm{J}=8.0 \mathrm{~Hz}), 6.15(\mathrm{~m}, 1 \mathrm{H})$, $4.66(\mathrm{~s}, 2 \mathrm{H}), 4.39(\mathrm{bs}, 1 \mathrm{H}), 4.42(\mathrm{q}, 2 \mathrm{H}, \mathrm{J}=7.2 \mathrm{~Hz}), 1.40(\mathrm{t}, 3 \mathrm{H}, \mathrm{J}=7.2 \mathrm{~Hz}) .{ }^{13} \mathrm{C} \mathrm{NMR}$ $\left(\mathrm{CDCl}_{3}\right): \delta 165.2,160.4,148.0,138.8,136.0,134.2,128.4,126.9,125.4,125.3,122.2$, 120.3, 111.4, 100.8, 62.4, 60.9, 14.2. Mass Spectrum (M+1): Expected for $\mathrm{C}_{17} \mathrm{H}_{16} \mathrm{~N}_{2} \mathrm{O}_{3}$ : 297.12. Found: 297.12. Elemental Analysis: Calcd. for $\mathrm{C}_{17} \mathrm{H}_{16} \mathrm{~N}_{2} \mathrm{O}_{3}: \mathrm{C}, 68.91 ; \mathrm{H}, 5.44 ; \mathrm{N}$, 9.45. Found: C, 69.13; H, 5.26; N, 9.33.

Alternatively, the product could also be made using $\mathrm{Ca}\left(\mathrm{BH}_{4}\right)_{2}$ as the reducing reagent in the same solvent and temperature for same period of time. The NMR, mass spectrum, elemental analysis and mp. of this product were identical to that of the product obtained by the previous method. The yield of this reaction was $85 \%$. 


\section{6-formyl-5-(4-indolyl)-nicotinic acid ethyl ester (9c):}<smiles>CCOC(=O)c1cnc(C)c(-c2cccc3[nH]ccc23)c1</smiles>

To a solution of 6-hydroxymethyl-5-(4-indolyl)-nicotinic acid ethyl ester (296 mg, 1.0 mmol) in $5 \mathrm{ml} \mathrm{CH} \mathrm{Cl}_{2}$ was added freshly made $\mathrm{MnO}_{2}(870 \mathrm{mg}, 10.0 \mathrm{mmol})$. The reaction was stirred at r.t. for 2 hours then filtered from the solution through a plug of celite, and the solvent was removed in vacuo. Purification of the crude material by silica gel chromatography using hexane-ethyl acetate $(2: 1)$ afforded a yellow solid $(271 \mathrm{mg}$, 92\%) with mp. 198.4-199.2 ${ }^{\circ} \mathrm{C}$. ${ }^{1} \mathrm{H}$ NMR $\left(\mathrm{CDCl}_{3}\right): \delta 10.03(\mathrm{~s}, 1 \mathrm{H}), 9.22(\mathrm{~d}, 1 \mathrm{H}, \mathrm{J}=1.6 \mathrm{~Hz})$, $8.61(\mathrm{~d}, 1 \mathrm{H}, \mathrm{J}=1.6 \mathrm{~Hz}), 8.47(\mathrm{bs}, 1 \mathrm{H}), 7.56(\mathrm{~d}, 1 \mathrm{H}, \mathrm{J}=8.0 \mathrm{~Hz}), 7.35-7.25(\mathrm{~m}, 2 \mathrm{H}), 7.08(\mathrm{~d}$, $1 \mathrm{H}, \mathrm{J}=8.0 \mathrm{~Hz}), 6.26(\mathrm{~m}, 1 \mathrm{H}), 4.42(\mathrm{q}, 2 \mathrm{H}, \mathrm{J}=7.2 \mathrm{~Hz}), 1.42(\mathrm{t}, 3 \mathrm{H}, \mathrm{J}=7.2 \mathrm{~Hz}) .{ }^{13} \mathrm{C}$ NMR $\left(\mathrm{CDCl}_{3}\right): \delta 190.8,164.2,150.8,149.6,140.9,140.1,136.7,128.4,127.8,127.2,126.1$, 122.1, 121.9, 112.0, 100.6, 61.7, 14.2. Mass Spectrum (M+1): Expected for $\mathrm{C}_{17} \mathrm{H}_{14} \mathrm{~N}_{2} \mathrm{O}_{3}$ : 295.10. Found: 295.10. Elemental Analysis: Calcd. for $\mathrm{C}_{17} \mathrm{H}_{14} \mathrm{~N}_{2} \mathrm{O}_{3}$ : C, 69.38; H, 4.79; $\mathrm{N}$, 9.52. Found: C, $69.58 ; \mathrm{H}, 4.83 ; \mathrm{N}, 9.64$.

\section{6-Hydroxy-4,6-dihydro-indolo[4,3-fg]quinoline-9-carboxylic acid methyl ester (10):}<smiles>CC(=O)c1cnc2c(c1)-c1cccc3[nH]cc(c13)C2O</smiles>

To a solution of 6-formyl-5-(4-indolyl)-nicotinic acid ethyl ester (117.8 $\mathrm{mg}, 0.4 \mathrm{mmol})$ in anhydrous methanol $(1.0 \mathrm{ml})$ in a $2 \mathrm{ml}$ conical vial was added $0.5 \mathrm{M} \mathrm{NaOMe} / \mathrm{MeOH}$ ( $16.0 \mu 1,0.008 \mathrm{mmol})$. The reaction was stirred at r.t. for 2 hours. Solid precipitated out of the solution during the course of the reaction, and the starting material disappeared completely after 2 hours as indicated by TLC. The solution was cooled to $0^{\circ} \mathrm{C}$ and the liquid was removed with a pipette. The remaining solid was recrystallized from $\mathrm{MeOH}$ to afford $102.0 \mathrm{mg}$ yellow crystalline solid (mp. $234.6-235.8^{\circ} \mathrm{C}$ ) in $91 \%$ yield. ${ }^{1} \mathrm{H}$ NMR $\left(\mathrm{CDCl}_{3}\right): \delta 9.52(\mathrm{~d}, 1 \mathrm{H}, \mathrm{J}=1.6 \mathrm{~Hz}), 9.45(\mathrm{~d}, 1 \mathrm{H}, \mathrm{J}=1.6 \mathrm{~Hz}), 8.55(\mathrm{bs}, 1 \mathrm{H}), 7.96(\mathrm{~s}, 1 \mathrm{H}), 7.82$ $(\mathrm{d}, 1 \mathrm{H}, \mathrm{J}=8.0 \mathrm{~Hz}), 7.58(\mathrm{t}, 1 \mathrm{H}, \mathrm{J}=8.0 \mathrm{~Hz}), 6.81(\mathrm{~d}, 1 \mathrm{H}, \mathrm{J}=8.0 \mathrm{~Hz}), 6.54(\mathrm{bs}, 1 \mathrm{H}), 5.22$ (bs, 
$1 \mathrm{H}), 4.05(\mathrm{~s}, 3 \mathrm{H}) .{ }^{13} \mathrm{C} \mathrm{NMR}\left(\mathrm{CDCl}_{3}\right): \delta 166.1,152.3,149.4,148.2,142.8,133.8,131.6$, 128.1, 125.9, 123.9, 122.6, 121.0, 111.2, 104.1, 90.4, 52.2. Mass Spectrum $(\mathrm{M}+1)$ : Expected for $\mathrm{C}_{16} \mathrm{H}_{12} \mathrm{~N}_{2} \mathrm{O}_{3}$ : 281.08. Found: 281.08. Elemental Analysis: Calcd. for $\mathrm{C}_{16} \mathrm{H}_{12} \mathrm{~N}_{2} \mathrm{O}_{3}$ : C, 68.56; H, 4.32; N, 9.99. Found: C, 68.43; H, 4.48; N, 10.19 .

\section{4,6-Dihydro-indolo[4,3-fg]quinoline-9-carboxylic acid methyl ester (11):}<smiles>CC(=O)c1cnc2c(c1)-c1cccc3[nH]cc(c13)C2</smiles>

To a solution of 6-hydroxy-4,6-dihydro-indolo[4,3-fg]quinoline-9-carboxylic methyl ester $(90 \mathrm{mg}, 0.32 \mathrm{mmol})$ in $10 \mathrm{ml}$ anhydrous THF was added $\mathrm{BH}_{3}$ in THF $(1.0 \mathrm{M}, 0.64$ $\mathrm{ml}, 0.64 \mathrm{~mol})$ under argon. The resulting mixture was stirred at r.t. for 2 hours. The TLC showed the disappearance of the starting material and a new fluorescent spot under UV on TLC. The solvent was removed in vacuo and the crude material was partitioned between $\mathrm{CH}_{2} \mathrm{Cl}_{2}(3 \mathrm{ml})$ and aq. $\mathrm{NaHCO}_{3}$ (sat., $2 \mathrm{ml}$ ). The organic layer was separated and the aqueous was extracted with additional $\mathrm{CH}_{2} \mathrm{Cl}_{2}(3 \mathrm{ml} \times 2)$. The combined organic layers were dried over $\mathrm{Na}_{2} \mathrm{SO}_{4}$ and concentrated. The crude material was purified by silica gel PTLC using $\mathrm{CH}_{2} \mathrm{Cl}_{2}$ : $\mathrm{MeOH}$ (98:2). A white solid was obtained (mp. 212.9$\left.213.9^{\circ} \mathrm{C}, 35.2 \mathrm{mg}\right)$ in $41 \%$ yield. ${ }^{1} \mathrm{H} \mathrm{NMR}\left(\mathrm{CDCl}_{3}\right): \delta 9.44(\mathrm{~d}, 1 \mathrm{H}, \mathrm{J}=1.6 \mathrm{~Hz}), 9.40(\mathrm{~d}, 1 \mathrm{H}$, $\mathrm{J}=1.6 \mathrm{~Hz}), 8.07(\mathrm{bs}, 1 \mathrm{H}), 7.75(\mathrm{~d}, 1 \mathrm{H}, \mathrm{J}=8.0 \mathrm{~Hz}), 7.70(\mathrm{~s}, 1 \mathrm{H}), 7.54(\mathrm{t}, 1 \mathrm{H}, \mathrm{J}=8.0 \mathrm{~Hz}), 6.78$ $(\mathrm{d}, 1 \mathrm{H}, \mathrm{J}=8.0 \mathrm{~Hz}), 4.98(\mathrm{~s}, 2 \mathrm{H}), 4.04(\mathrm{~s}, 3 \mathrm{H}) .{ }^{13} \mathrm{C} \mathrm{NMR}\left(\mathrm{CDCl}_{3}\right): \delta 164.0,149.6,147.2$, $146.1,141.0,135.2,129.3,126.4,124.2,122.6,120.9,119.8,110.1,103.6,55.2,51.4$. Mass Spectrum $(\mathrm{M}+1)$ : Expected for $\mathrm{C}_{16} \mathrm{H}_{12} \mathrm{~N}_{2} \mathrm{O}_{2}$ : 265.09. Found: 265.09. Elemental Analysis: Calcd. for $\mathrm{C}_{16} \mathrm{H}_{12} \mathrm{~N}_{2} \mathrm{O}_{2}$ : C, 72.72; H, 4.58; N, 10.60. Found: C, 72.58; H, 4.72; $\mathrm{N}, 10.68$.

\section{2. \pm Lysergic acid (1):}<smiles>CN1C[C@H](C(=O)O)C=C2c3cccc4[nH]cc(c34)C[C@H]21</smiles> 
To a solution of 4,6-dihydro-indolo[4,3-fg]quinoline-9-carboxylic acid methyl ester (29.2 $\mathrm{mg}, 0.116 \mathrm{mmol})$ in $\mathrm{CH}_{2} \mathrm{Cl}_{2}(1 \mathrm{ml})$ was added $\mathrm{MeI}(33.0 \mathrm{mg}, 14.6 \mu \mathrm{l}, 0.24 \mathrm{mmol})$ at $0^{\circ} \mathrm{C}$. The reaction was stirred at $0^{\circ} \mathrm{C}$ for 2 hours and the starting material disappeared after 2 hours as indicated by TLC. The solvent was removed in vacuo and the crude product was dissolved in methanol $(1 \mathrm{ml})$. To that mixture was added $\mathrm{NaBH}_{4}(15.2 \mathrm{mg}$, $0.4 \mathrm{mmol}$ ) and the reaction was stirred at r.t. for $5 \mathrm{~min}$. The organic solvent was removed in vacuo and the remaining solution was partitioned between $\mathrm{CH}_{2} \mathrm{Cl}_{2}(2 \mathrm{ml})$ and water $(2$ $\mathrm{ml})$. The organic layer was separated and the aqueous layer was extracted with additional $\mathrm{CH}_{2} \mathrm{Cl}_{2}(3 \mathrm{ml} \times 2)$. The organic layers were combined and dried over $\mathrm{Na}_{2} \mathrm{SO}_{4}$. The solvent was removed and the crude material was purified by PTLC $\left(\mathrm{CH}_{2} \mathrm{Cl}_{2}: \mathrm{MeOH}, 98\right.$ : 2). A white solid was obtained $(21.4 \mathrm{mg}, 65 \%) .{ }^{1} \mathrm{H}$ NMR showed it to be a mixture of methyl lysergate and methyl isolysergate in $6: 1$ ratio using $\mathrm{N}$-methyl as the integration indicator. ${ }^{1} \mathrm{H}$ NMR $\left(\mathrm{CDCl}_{3}\right)$ of methyl lysergate: $\delta 7.90$ (bs, $\left.1 \mathrm{H}\right), 7.15-7.25(\mathrm{~m}, 3 \mathrm{H}), 6.92$ (t, $1 \mathrm{H}, \mathrm{J}=2.0 \mathrm{~Hz}), 6.62(\mathrm{bs}, 1 \mathrm{H}), 3.78(\mathrm{~s}, 3 \mathrm{H}), 3.75(\mathrm{~m}, 1 \mathrm{H}), 3.52(\mathrm{dd}, 1 \mathrm{H}, \mathrm{J}=14.0,6.0 \mathrm{~Hz})$, 3.29 (br dd, $1 \mathrm{H}, \mathrm{J}=11.0,5.0 \mathrm{~Hz}), 3.22(\mathrm{~m}, 1 \mathrm{H}), 2.72$ (ddd, $1 \mathrm{H}, \mathrm{J}=14.0,12.0,2.0 \mathrm{~Hz}), 2.70$ $(\mathrm{t}, 1 \mathrm{H}, \mathrm{J}=11.0 \mathrm{~Hz}), 2.62(\mathrm{~s}, 3 \mathrm{H}) .{ }^{1} \mathrm{H}$ NMR $\left(\mathrm{CDCl}_{3}\right)$ of methyl isolysergate: $\delta 7.90(\mathrm{bs}, 1 \mathrm{H})$, 7.15-7.25 (m, 3H), $6.90(\mathrm{t}, 1 \mathrm{H}, \mathrm{J}=2.0 \mathrm{~Hz}), 6.56(\mathrm{br} \mathrm{d}, 1 \mathrm{H}, \mathrm{J}=4.0 \mathrm{~Hz}), 3.72(\mathrm{~s}, 3 \mathrm{H}), 3.42$ (dd, $1 \mathrm{H}, \mathrm{J}=14.0,5.0 \mathrm{~Hz}), 3.35(\mathrm{~m}, 1 \mathrm{H}), 3.30(\mathrm{~m}, 1 \mathrm{H}), 3.30(\mathrm{~m}, 1 \mathrm{H}), 3.20(\mathrm{~m}, 1 \mathrm{H}), 2.73$ (ddd, $1 \mathrm{H}, \mathrm{J}=14.0,11.0,2.0 \mathrm{~Hz}), 2.74(\mathrm{~m}, 1 \mathrm{H}), 2.57(\mathrm{~s}, 3 \mathrm{H})$

These ${ }^{1} \mathrm{H}$ NMR data are in agreement with that of methyl lysergate and methyl isolysergate synthesized by $\operatorname{Ninomyia}^{4 \mathrm{c}}$. Mass Spectrum $(\mathrm{M}+1)$ : Expected for $\mathrm{C}_{17} \mathrm{H}_{18} \mathrm{~N}_{2} \mathrm{O}_{2}$ : 283.14. Found: 283.14. Elemental Analysis: Calcd. for $\mathrm{C}_{17} \mathrm{H}_{18} \mathrm{~N}_{2} \mathrm{O}_{2}$ : C, 72.32; H, 6.43; N, 9.92. Found: C, 72.20; H, 6.41; N, 10.05 .

To a solution of methyl lysergate \& methyl isolysergate $(6: 1$ mixture above, $15.6 \mathrm{mg}$, $0.028 \mathrm{mmol})$ in ethanol $(0.5 \mathrm{ml})$ was added $1 \mathrm{~N} \mathrm{NaOH}(0.5 \mathrm{ml})$. The reaction was heated at $35^{\circ} \mathrm{C}$ for two hours. $0.1 \mathrm{~N} \mathrm{HCl}$ solution was used to carefully adjust the $\mathrm{pH}$ to 6 and the solid material was collected by removing the liquid. The solid was recrystallized from ethanol to afford $12.2 \mathrm{mg},(95 \%)$ of lysergic acid. ${ }^{1} \mathrm{H}$ NMR (pyridine- $\left.\mathrm{d}_{5}\right)$ of \pm lysergic acid: $\delta 7.44(\mathrm{~d}, 1 \mathrm{H}, \mathrm{J}=8.4 \mathrm{~Hz}), 7.42(\mathrm{~d}, 1 \mathrm{H}, \mathrm{J}=8.4 \mathrm{~Hz}), 7.31(\mathrm{t}, 1 \mathrm{H}, \mathrm{J}=8.4 \mathrm{~Hz}), 7.25(\mathrm{t}, 1 \mathrm{H}$, $\mathrm{J}=1.6 \mathrm{~Hz})$ ), $7.20(\mathrm{bs}, 1 \mathrm{H}), 4.05(\mathrm{~m}, 1 \mathrm{H}), 3.63(\mathrm{dd}, 1 \mathrm{H}, \mathrm{J}=14.4,6.4 \mathrm{~Hz}), 3.52(\mathrm{dd}, 1 \mathrm{H}$, $\mathrm{J}=11.2,5.2 \mathrm{~Hz}), 3.29(\mathrm{~m}, 1 \mathrm{H}), 2.93(\mathrm{ddd}, 1 \mathrm{H}, \mathrm{J}=14.4,11.2,2.0 \mathrm{~Hz}), 2.71(\mathrm{t}, 1 \mathrm{H}$, $\mathrm{J}=11.2 \mathrm{~Hz}$ ), $2.50(\mathrm{~s}, 3 \mathrm{H}) .{ }^{1} \mathrm{H}$ NMR (methanol- $\left.\mathrm{d}_{4}\right)$ of \pm lysergic acid: $\delta 7.22(\mathrm{~d}, 1 \mathrm{H}$, $\mathrm{J}=8.4 \mathrm{~Hz}), 7.18(\mathrm{~d}, 1 \mathrm{H}, \mathrm{J}=8.4 \mathrm{~Hz}), 7.12(\mathrm{t}, 1 \mathrm{H}, \mathrm{J}=8.4 \mathrm{~Hz}), 7.05(\mathrm{t}, 1 \mathrm{H}, \mathrm{J}=2.0 \mathrm{~Hz}), 6.65(\mathrm{bs}$, $1 \mathrm{H}), 4.15(\mathrm{~m}, 1 \mathrm{H}), 3.70(\mathrm{~m}, 3 \mathrm{H}), 3.42(\mathrm{t}, 1 \mathrm{H}, \mathrm{J}=11.2 \mathrm{~Hz}), 2.91$ (ddd, $1 \mathrm{H}, \mathrm{J}=14,12,2 \mathrm{~Hz})$. ${ }^{13} \mathrm{C}$ NMR (pyridine- $\mathrm{d}_{5}$ ) $: \delta 174.9,137.2,136.4,130.2,128.9,127.3,119.8,119.6,112.0$, 111.5, 111.3, 63.5, 56.1, 43.8, 43.4, 27.3. Mass Spectrum (M+1): Expected for $\mathrm{C}_{16} \mathrm{H}_{16} \mathrm{~N}_{2} \mathrm{O}_{2}$ : 269.12. Found: 269.12. Elemental Analysis: Calcd. for $\mathrm{C}_{16} \mathrm{H}_{16} \mathrm{~N}_{2} \mathrm{O}_{2}$ : C, 71.62; H, 6.01; N, 10.44. Found: C, 71.54; H, 5.88; N, 10.31. 